\title{
Effects of rapidly imposed water deficit on photosynthetic parameters of three $\mathrm{C}_{4}$ grasses
}

\author{
A.S. SOARES-CORDEIRO ${ }^{*,+}$, A.E. CARMO-SILVA ${ }^{*, *}$, A. BERNARDES DA SILVA* ${ }^{*}$ J. MARQUES DA \\ SILVA*, A.J. KEYS ${ }^{* *}$, and M.C. ARRABAÇA* \\ Centro de Engenharia Biológica and Departamento de Biologia Vegetal, Faculdade de Ciências da Universidade \\ de Lisboa, Campo Grande, 1749-016 Lisboa, Portugal \\ Department of Plant Sciences, Centre for Crop Genetic Improvement, Rothamsted Research, Harpenden, \\ Hertfordshire, AL5 $2 J Q, U K^{* *}$
}

\begin{abstract} between the three species.

Many plants, in their natural environment, are subjected to cycles of water stress and recovery, which may become more severe with global climate change. $\mathrm{C}_{4}$ plants are reputed to be better adapted to higher temperatures and drought than $C_{3}$ plants (Long 1999). Decreased net photosynthesis by $\mathrm{C}_{4}$ plants under water deficit (Lal and Edwards 1996, Heckathorn et al. 1997, Ghannoum et al. 2003, Marques da Silva and Arrabaça 2004a, Carmo-Silva et al. 2007) may result from stomatal closure alone or together with non-stomatal factors. The photochemical apparatus of $\mathrm{C}_{4}$ plants is resistant to moderate water deficit (Loreto et al. 1995, Ghannoum et al. 2003, Marques da Silva and Arrabaça 2004a) but may be impaired under severe drought. Studies of the effect of dehydration on carboxylating and decarboxyl-
\end{abstract}

Water deficit, when rapidly imposed on three $\mathrm{C}_{4}$ grasses of the different metabolic subtypes, Paspalum dilatatum Poiret (NADP-malic enzyme), Cynodon dactylon (L.) Pers (NAD-malic enzyme) and Zoysia japonica Steudel (phosphoenolpyruvate carboxykinase), caused decreases in photosynthetic rates, in the quantum yield of PS II and photochemical quenching, and in the activities of ribulose-1,5-bisphosphate carboxylase/oxygenase (Rubisco) and phosphoenolpyruvate carboxylase (PEPC). The results provide evidence for non-stomatal limitations of photosynthesis differing in nature

Additional key words: chlorophyll a fluorescence; drought stress; NAD-malic enzyme; NADP-malic enzyme; phosphoenolpyruvate carboxykinase; phosphoenolpyruvate carboxylase; photosynthetic capacity; Rubisco.

ating enzyme activities in $\mathrm{C}_{4}$ plants (Du et al. 1996, Saccardy et al. 1996, Foyer et al. 1998, Castrillo et al. 2001, Marques da Silva and Arrabaça 2004b,) have produced conflicting results concerning possible roles in the limitation of photosynthesis.

Photosynthetic rate measured by oxygen evolution at saturating $\mathrm{CO}_{2}$ and high irradiance should be limited mainly by non-stomatal factors. We investigated the effects of water deficit on various photosynthetic parameters in three $\mathrm{C}_{4}$ grasses belonging to different metabolic subtypes: Paspalum dilatatum Poiret (NADPmalic enzyme, NADP-ME), Cynodon dactylon (L.) Pers (NAD-malic enzyme; NAD-ME) and Zoysia japonica Steudel (phosphoenolpyruvate carboxykinase; PEPCK). The main objectives were to compare the response of the

Received 23 October 2008, accepted 9 June 2009.

${ }^{+}$Corresponding author; fax: 003512175000 48, e-mail: anascs@netcabo.pt

Abbreviations: DM - dry mass; NAD-ME - NAD-malic enzyme; NADP-ME - NADP-malic enzyme; NPQ - non-photochemical quenching; PEPC - phosphoenolpyruvate carboxylase; PEPCK - phosphoenolpyruvate carboxykinase; $P_{\max }$ - rate of photosynthesis at saturating $\mathrm{CO}_{2}$ and high irradiance; PPFD - photosynthetic photon flux density; PSII - photosystem II; $\mathrm{q}_{\mathrm{P}}-$ photochemical quenching; Rubisco - ribulose-1,5-bisphosphate carboxylase/oxygenase; RWC - leaf relative water content; $\mathrm{V}_{\max }-\mathrm{PEPC}$ maximal activity; $\mathrm{V}_{\mathrm{t}}-$ Rubisco total activity; $\Phi_{\mathrm{PSII}}-$ effective quantum yield of PS II electron transport.

Acknowledgements: This work was partially supported by 'Programa de Desenvolvimento Educativo para Portugal' (PRODEP III) and by 'Federação Portuguesa de Golfe'. The authors thank Margot Forde Forage Germplasm Centre, New Zealand, and Dr. Daniel Ribeiro, Geodesenho, Portugal, for providing seeds of the $\mathrm{C}_{4}$ grasses. The authors thank Ms. Manuela Lucas, Centro de Engenharia Biológica, Faculdade de Ciências da Universidade de Lisboa, Portugal, for technical assistance. A.S. Soares-Cordeiro and A.E. Carmo-Silva contributed in equal parts to the work presented. 
three species to rapidly induced water deficit and to identify photochemical and/or metabolic processes causing decreased $\mathrm{CO}_{2}$ - and light-saturated photosynthesis.

Plants of the three species were grown hydroponically and subjected to a rapidly imposed water deficit with polyethylene glycol 4000, as previously described (Carmo-Silva et al. 2007). Measurements were made on the widest part of young fully expanded leaves, equidistant from the two ends, and started 20 to $28 \mathrm{~h}$ after water deficit induction and two hours after the beginning of the photoperiod. The leaf relative water content (RWC) was determined according to Čatský (1960). The rate of photosynthesis $\left(P_{\max }\right)$ was measured by $\mathrm{O}_{2}$ evolution using a gas-phase oxygen electrode ( $L D 2$,
Hansatech Instruments Ltd, King's Lynn, Norkfolk, UK) at saturating $\mathrm{CO}_{2}\left(0.07 \mathrm{~m}^{3} \mathrm{~m}^{-3}\right)$ (Marques da Silva and Arrabaça 2004a), at $25^{\circ} \mathrm{C}$ and at a photosynthetic photon flux density (PPFD) of $1100 \mu \mathrm{mol}$ (photon) $\mathrm{m}^{-2} \mathrm{~s}^{-1}$ (LS2 Light Source, Hansatech Instruments Ltd, King's Lynn, Norkfolk, UK). The leaf fresh mass, dry mass (DM) and area (portable area meter LI-3000, LI-COR Inc., Lincoln, Nebraska, USA) enclosed in the electrode chamber were determined. Chlorophyll $a$ fluorescence parameters were measured at room temperature and at ambient atmospheric $\mathrm{CO}_{2}$ using a pulsed amplitude modulation fluorometer (PAM-210 with DA-TEACH 1.01 software, Heinz Walz GmbH, Effeltrich, Germany) as previously described (Carmo-Silva et al. 2007), but with an actinic

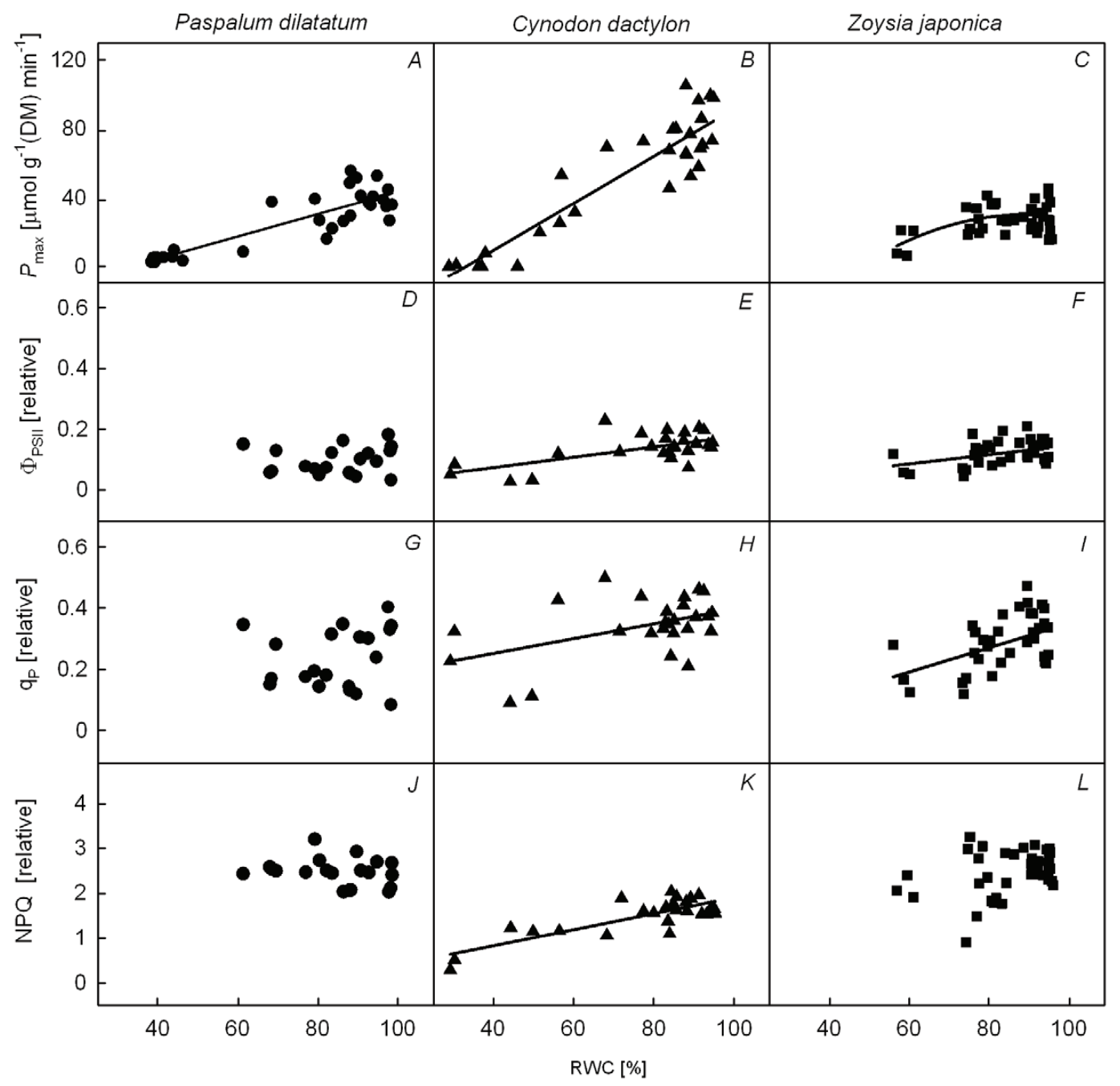

Fig. 1. Rate of photosynthesis at saturating $\mathrm{CO}_{2}$ and high irradiance $\left(P_{\max }\right)(A-C)$, effective quantum yield of PSII electron transport $\left(\Phi_{\mathrm{PSII}}\right)(D-F)$, photochemical quenching $\left(\mathrm{q}_{\mathrm{P}}\right)(G-I)$ and non-photochemical quenching (NPQ) $(J-L)$ at different leaf relative water contents (RWC) in the leaves of Paspalum dilatatum $\left(A, \mathrm{y}=0.65 \mathrm{x}-21.7, r^{2}=0.73 ; D ; G ; J\right)$, Cynodon dactylon $(B, \mathrm{y}=1.36 \mathrm{x}$ $\left.-45.23, r^{2}=0.83 ; E, \mathrm{y}=0.0017 \mathrm{x}+0.0057, r^{2}=0.40 ; H, \mathrm{y}=0.0024 \mathrm{x}+0.156, r^{2}=0.22 ; K, \mathrm{y}=0.018 \mathrm{x}+0.093, r^{2}=0.66\right)$ and Zoysia japonica $\left(C, \mathrm{y}=-0.018 \mathrm{x}^{2}+3.14 \mathrm{x}-109.62, r^{2}=0.26 ; F, \mathrm{y}=0.0014 \mathrm{x}+0.0036, r^{2}=0.14 ; I, \mathrm{y}=0.0039 \mathrm{x}-0.049, r^{2}=0.23\right.$; $L)$. Gas-exchange measurements were performed at $25^{\circ} \mathrm{C}, 0.07 \mathrm{~m}^{3} \mathrm{~m}^{-3} \mathrm{CO}_{2}$ and a PPFD of $1100 \mu$ mol(photon) $\mathrm{m}^{-2} \mathrm{~s}^{-1}$. Chlorophyll $a$ measurements were obtained under an actinic light intensity of $1850 \mu \mathrm{mol}\left(\right.$ photon) $\mathrm{m}^{-2} \mathrm{~s}^{-1}$. Each data point represents a different sample. 


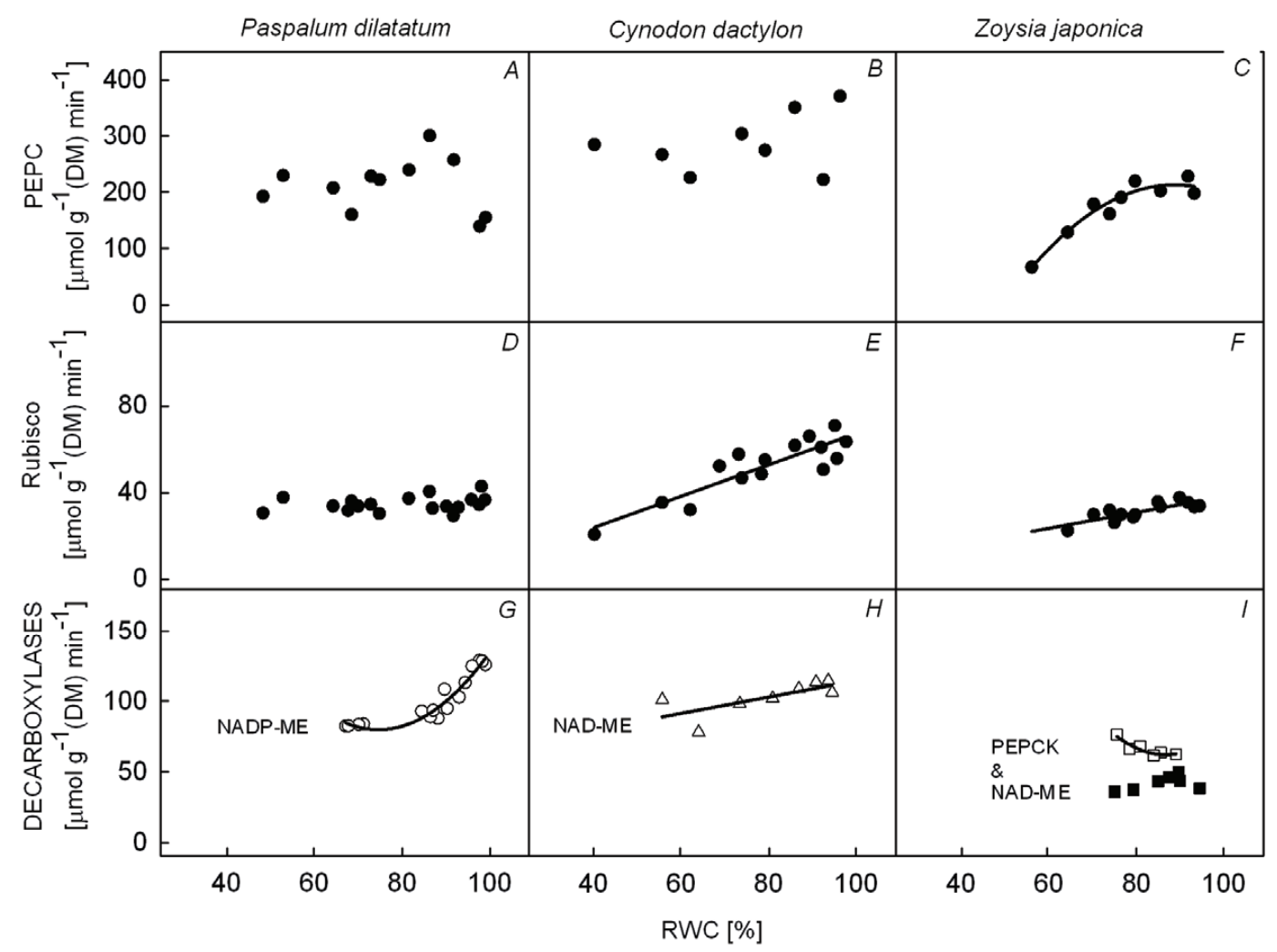

Fig. 2. Activities of PEPC $(A-C)$, Rubisco $(D-F)$ and of the decarboxylases NADP-ME (open circles), NAD-ME (open triangles and closed squares) and PEPCK (open squares) $(G-I)$, at different leaf relative water contents (RWC) in the leaves of Paspalum dilatatum $\left(A ; D ; G, \mathrm{y}=0.08 \mathrm{x}^{2}-12.76 \mathrm{x}+556.32, r^{2}=0.93\right)$, Cynodon dactylon $\left(B ; E, \mathrm{y}=0.67 \mathrm{x}-4.86, r^{2}=0.78 ; H, \mathrm{y}=0.58 \mathrm{x}+57.10\right.$, $\left.r^{2}=0.51\right)$ and Zoysia japonica $\left(C, \mathrm{y}=-0.14 \mathrm{x}^{2}+24.34 \mathrm{x}-866.0, r^{2}=0.93 ; F, \mathrm{y}=0.34 \mathrm{x}+1.36, r^{2}=0.34 ; I, \mathrm{y}=0.11 \mathrm{x}^{2}-18.25 \mathrm{x}+\right.$ $\left.852.75, r^{2}=0.87\right)$. Each data point represents a different sample.

light of $1850 \mu \mathrm{mol}\left(\right.$ photon) $\mathrm{m}^{-2} \mathrm{~s}^{-1}$. Plants were darkadapted for $4 \mathrm{~min}$, then illuminated for $5 \mathrm{~min}$ before determining the steady-state value of fluorescence. A saturating light of $4000 \mu \mathrm{mol}$ (photon) $\mathrm{m}^{-2} \mathrm{~s}^{-1}$ for $0.9 \mathrm{~s}$ was used for the measurements. Where necessary, leaves of $Z$. japonica were uncurled. Leaf samples for enzyme activity measurements were collected inside the growth chamber into liquid nitrogen and stored at $-80{ }^{\circ} \mathrm{C}$. Crude extracts for measuring the activities of ribulose1,5-bisphosphate carboxylase/oxygenase (Rubisco, EC 4.1.1.39), phosphoenolpyruvate carboxylase (PEPC, EC 4.1.1.31), NADP-ME (EC 1.1.1.40), NAD-ME (EC 1.1.1.39) and PEPCK (EC 4.1.1.49) were obtained as described previously by Carmo-Silva et al. (2007), except that, for PEPCK, $200 \mathrm{mM}$ Bicine-KOH (pH 9.8) was used and $50 \mathrm{mM}$ DTT was added, as proposed by Walker et al. (2002). Triplicate measurements of activities were made on each leaf extract. PEPC maximal activity $\left(\mathrm{V}_{\max }\right)$ was measured spectrophotometrically at $340 \mathrm{~nm}$ and $25^{\circ} \mathrm{C}$ according to Bakrim et al. (1992) with some modifications (Carmo-Silva et al. 2007). Rubisco total activity $\left(\mathrm{V}_{\mathrm{t}}\right)$ was assayed at $25{ }^{\circ} \mathrm{C}$ by ${ }^{14} \mathrm{CO}_{2}$ incorporation into acid-stable products by the method of Parry et al. (1997). The decarboxylating enzymes activities were measured essentially as described by Ashton et al. (1990) for NADP-ME and NAD-ME and by Walker et al. (2002) for PEPCK. Regression analysis was applied to assess the changes induced by leaf dehydration on each measured parameter using the Statistical Package for Social Sciences (SPSS) 12.0, 2003 (SPSS Inc., Chicago, Illinois, USA). Models that best explained the results were selected on the basis of an $F$ test of probability $(p<0.05)$.

Decreased $P_{\max }$ with water deficit in all three species (Fig. 1 $A-C$ ) suggested the involvement of non-stomatal factors in the limitation of photosynthesis. In P. dilatatum and $C$. dactylon, $P_{\max }$ decreased linearly, as reported by Marques da Silva and Arrabaça (2004a), but in Z. japonica $P_{\max }$ decreased only when RWC fell below ca. $80 \%$, as observed by Lal and Edwards (1996).

Chlorophyll $a$ fluorescence indicated photochemical impairment at high irradiance in dehydrated leaves of C. dactylon and $Z$. japonica, but not in $P$. dilatatum (Fig. $1 D-L$ ). The decrease in the effective quantum yield of PS II electron transport $\left(\Phi_{\mathrm{PSII}}\right)$ in $C$. dactylon and $Z$.japonica (Fig. 1E,F) may have contributed to the decrease in $P_{\max }$ with drought. Ghannoum et al. (2003) and Marques da Silva and Arrabaça (2004a) reported a linear decrease of $\Phi_{\mathrm{PSII}}$ and photochemical quenching $\left(\mathrm{q}_{\mathrm{P}}\right)$ with drought in $\mathrm{C}_{4}$ plants, whereas Loreto et al. (1995) and Lal and Edwards (1996) found decreases only when 
RWC decreased below $75 \%$. The constancy, or decrease of non-photochemical quenching (NPQ) under water deficit (Fig. 1J-L), together with decreased $P_{\max }$ (Fig. $1 A-C$ ), suggest that alternative electron sinks dissipate the excess excitation energy in the three species under drought. Since the major component of the NPQ is the energy-dependent quenching, a decrease in NPQ may reflect the incapacity to maintain the transthylakoidal proton gradient or the presence of proton leakage.

In the three $\mathrm{C}_{4}$ grasses PEPC $\mathrm{V}_{\max }$ (Fig. $2 A-C$ ) was always much higher than $P_{\max }$ (Fig. $1 A-C$ ) and was only affected by water deficit in $Z$. japonica when RWC decreased below $80 \%$. Thus PEPC activity could limit $P_{\max }$ only in $Z$. japonica at severe water deficit. Rubisco $\mathrm{V}_{\mathrm{t}}$ was relatively unaffected in $P$. dilatatum but decreased linearly in $C$. dactylon with decreasing RWC (Fig. 2D,E) and may have contributed to limit photosynthetic $\mathrm{CO}_{2}$ assimilation in this species. A less pronounced decrease of Rubisco $\mathrm{V}_{\mathrm{t}}$ was observed in $Z$. japonica (Fig. $2 F$ ). Decreased Rubisco activity under water deficit suggests a decrease in amount of protein or down-regulation by tight-binding inhibitors (Parry et al. 1993, 2002). In the fully hydrated leaves of $P$. dilatatum and $C$. dactylon, Rubisco $\mathrm{V}_{\mathrm{t}}$ (Fig. 2D,E) was lower than $P_{\max }$ (Fig. $1 A, B$ ), perhaps because tight-binding inhibitors were present under the growing conditions. Rubisco activase activity is enhanced by illumination (Lan et al. 1992), so that under

\section{References}

Ashton, A.R., Burnell, J.N., Furbank, R.T., Jenkins, C.L.D., Hatch, M.D.: Enzymes of C4 photosynthesis. - In: Lea, P.J. (ed.): Methods in Plant Biochemistry. Enzymes of Primary Metabolism. Vol. 3. Pp. 39-72. Academic Press, London 1990.

Bakrim, N., Echevarria, C., Cretin, C., Arrio-Dupont, M., Pierre, J.N. Vidal, J., Chollet, R., Gadal, P.: Regulatory phosphorylation of sorghum leaf phosphoenolpyruvate carboxylase. Identification of the protein-serine kinase and some elements of the signal-transduction cascade. - Eur. J. Biochem. 204: 821-830, 1992.

Carmo-Silva, A.E., Soares, A.S., Marques da Silva, J., Bernardes da Silva, A., Keys, AJ., Arrabaça, M.C.: Photosynthetic responses of three $\mathrm{C} 4$ grasses of different metabolic subtypes to water deficit. - Funct. Plant Biol. 34: 204-213, 2007.

Castrillo, M., Fernandez, D., Calcagno, A.M., Trujillo, I., Guenni, L.: Responses of ribulose-1,5-bisphosphate carboxylase, protein content, and stomatal conductance to water deficit in maize, tomato, and bean. - Photosynthetica 39: 221226, 2001

Čatský, J.: Determination of water deficit in discs cut out from leaf blades. - Biol. Plant. 2: 76-77, 1960.

Du, Y.C., Kawamitsu, Y., Nose, A., Hiyane, S., Murayama, S., Wasano, K., Uchida, Y.: Effects of water stress on carbon exchange rate and activities of photosynthetic enzymes in leaves of sugarcane (Saccharum sp.). - Aust. J. Plant Physiol. 23: 719-726, 1996.

Foyer, C.H., Valadier, M.-H., Migge, A., Becker, T.W.: Drought-induced effects on nitrate reductase activity and the conditions used for $P_{\max }$ determination $[1100 \mu \mathrm{mol}$ (photon) $\mathrm{m}^{-2} \mathrm{~s}^{-1}$ ] more inhibitors may be removed from the catalytic sites of Rubisco, allowing higher enzyme activities to match the photosynthetic rates. Decarboxylating enzyme activities (Fig. 2G-I) were higher than $P_{\max }$ (Fig. $1 A-C$ ) in all three species, suggesting that the rate of decarboxylation in the bundle sheath was not a limiting step for photosynthesis. However, NADP-ME and NAD-ME activities decreased with water deficit in $P$. dilatatum and $C$. dactylon, respectively, and may have contributed to the decrease in $P_{\max }$. Drought-induced changes in the activities of PEPCK and NAD-ME in $Z$. japonica seem unlikely to have affected $P_{\max }$.

Under severe drought, $P_{\max }$ decreased to almost zero (Fig. $1 A-C$ ) but PEPC and Rubisco retained considerable activity (Fig. $2 A-F$ ). Ghannoum (2009) reported a more consistent inhibition of $\mathrm{C}_{3}$ than $\mathrm{C}_{4}$ cycle enzymes under water deficit. While this was true for $C$. dactylon, in $Z$. japonica PEPC was more affected than Rubisco and in $P$. dilatatum the carboxylating enzymes were not significantly affected, suggesting the presence of additional limitations to photosynthesis under water deficit. Distinct differences exist between $P$. dilatatum (NADP-ME), C. dactylon (NAD-ME) and Z. japonica (PEPCK) in the behaviour of $P_{\max }$, photochemical parameters and enzyme activities in response to rapid drought.

mRNA and on the coordination of nitrogen and carbon metabolism in maize leaves. - Plant Physiol. 117: 283-292, 1998.

Ghannoum, O.: C4 photosynthesis and water stress. - Ann. Bot. 103: 635-644, 2009.

Ghannoum, O., Conroy, J.P., Driscoll, S.P., Paul, M.J., Foyer, C.H., Lawlor, D.W.: Nonstomatal limitations are responsible for drought-induced photosynthetic inhibition in four $\mathrm{C} 4$ grasses. - New Phytol. 159: 599-608, 2003.

Heckathorn, S.A., DeLucia, E.H., Zielinski, R.E.: The contribution of drought-related decreases in foliar nitrogen concentration to decreases in photosynthetic capacity during and after drought in prairie grasses. - Physiol. Plant. 101: 173-182, 1997.

Lal, A., Edwards, E.: Analysis of inhibition of photosynthesis under water stress in the $\mathrm{C} 4$ species Amaranthus cruentus and Zea mays: electron transport, $\mathrm{CO}_{2}$ fixation and carboxylation capacity. - Aust. J. Plant Physiol. 23: 403-412, 1996.

Lan, Y., Woodrow, I.E., Mott, K.A: Light dependent changes in ribulose bisphosphate carboxylase activase activity in leaves. - Plant Physiol. 99: 304-309, 1992.

Long, S.P.: Environmental Responses. - In: Sage, R.F., Monson, R.K. (ed.): C4 Plant Biology. Pp. 215-249. Academic Press, New York 1999.

Loreto, F., Tricoli, D., Di Marco, G.: On the relationship between electron transport rate and photosynthesis in leaves of the C4 plant Sorghum bicolor exposed to water stress, temperature changes and carbon metabolism inhibition. Aust. J. Plant Physiol. 22: 885-892, 1995.

Marques da Silva, J., Arrabaça, M.C.: Photosynthesis in the water-stressed C4 grass Setaria sphacelata is mainly limited 
by stomata with both rapidly and slowly imposed water deficits. - Physiol. Plant. 121: 409-420, 2004a.

Marques da Silva, J., Arrabaça, M.C.: Photosynthetic enzymes of the C4 grass Setaria sphacelata under water stress: a comparison between rapidly and slowly imposed water deficit. - Photosynthetica 42: 43-47, 2004b.

Parry, M.A.J., Andralojc, P.J., Khan, S., Lea, P.J., Keys, A.J.: Rubisco activity: Effects of drought stress. - Ann. Bot. 89: 833-839, 2002.

Parry, M.A.J., Andralojc, P.J., Parmar, S., Keys, A.J., Habash, D., Paul, M.J., Alred, R., Quick, W.P., Servaites, J.C.: Regulation of Rubisco by inhibitors in the light. - Plant Cell Environ. 20: 528-534, 1997.
Parry, M.A.J., Delgado, E., Vadell, J., Keys, A.J., Lawlor, D.W., Medrano, H.: Water stress and the diurnal activity of ribulose-1,5-bisphosphate carboxylase in field grown Nicotiana tabacum genotypes selected for survival at low $\mathrm{CO}_{2}$ concentrations. - Plant Physiol. Biochem. 31: 113-120, 1993.

Saccardy, K., Cornic, G., Brulfert, J., Reyss, A.: Effect of drought stress on net $\mathrm{CO}_{2}$ uptake by Zea leaves. - Planta 199: 589-595, 1996.

Walker, R.P., Chen, Z.-H., Acheson, R.M., Leegood, R.C.: Effects of phosphorylation on phosphoenolpyruvate carboxykinase from the $\mathrm{C} 4$ plant guinea grass. - Plant Physiol. 128: 165-172, 2002. 